\title{
The Effects of Smoking on Periodontal Therapy: An Evidence-Based Comprehensive Literature Review
}

\author{
Mahmoud Abu-Ta'a \\ Department of Oral Surgery \& Periodontology, Faculty of Dentistry, Arab American University, West Bank, \\ Palestine \\ Email: mahmoud abutaa@yahoo.com
}

Received 3 January 2014; revised 6 February 2014; accepted 15 February 2014

Copyright (C) 2014 by author and Scientific Research Publishing Inc.

This work is licensed under the Creative Commons Attribution International License (CC BY). http://creativecommons.org/licenses/by/4.0/

c) (i) Open Access

\begin{abstract}
The positive relationship between smoking and major general health diseases such as cancer, cardiovascular disease, pulmonary disease and negative pregnancy outcomes is already established. Moreover, the association between smoking as a major environmental risk factor for periodontal disease has also been established. Smoking is considered to have negative adverse effect on periodontal therapy ranging from non-surgical treatment, periodontal surgery, regenerative procedures and implants. This review article will attempt to build on previous studies in the periodontal literature in order to present an evidence-based comprehensive literature review on the effects of smoking on periodontal therapy.
\end{abstract}

\section{Keywords}

Smoking; Cigarette Smoking; Periodontal Therapy; Regeneration; Implants

\section{Introduction}

Periodontitis or inflammation of the supporting tissues of teeth resulting in loss of connective tissue and alveolar bone support, results from complex interactions between pathogenic microorganisms in the biofilm, genetic and environmental factors especially tobacco use [1]. Tobacco smoking has been found to be the major environmental risk factor associated with an increased prevalence and severity of periodontal disease [2]. In addition to being positively linked with cardiovascular disease, lung disease, poor pregnancy outcomes and cancer; tobacco use has been reported to negatively affect the treatment outcomes of all periodontal procedures starting from mechanical debridement, local and systemic antimicrobial therapy, periodontal surgery, regenerative procedures 
and implants [3] [4].

It is clearly shown that the risk factor status of smoking to periodontal disease and periodontal therapy is strengthened by the ability to demonstrate a dose-response and years of exposure to tobacco products as risk factors for periodontal disease and periodontal therapy [5] [6]. However, it remains difficult to determine the strength of correlation of smoking as an environmental risk factor for periodontal disease and therapy due to inherent problems in determining accurately a subject's exposure to tobacco [7]-[9]. Therefore, it is generally supported in the literature that the more a patient smokes, the greater the degree of periodontal breakdown. It is also noted that periodontal therapy in non-smokers is more efficacious than in smokers [10]. Moreover, it has been shown that the response to periodontal therapy is related to the amount of cigarettes smoked [11].

Although it has often been stated that plaque-induced inflammation and occlusal loading are among the most important factors influencing the prognosis for oral implant treatment [12]-[14] smoking has become acknowledged as a leading predisposing factor in implant failure and particularly in multiple failures in the same individual [15] [16].

Taking into consideration the vast body of medical literature that describes the biological basis of smoking, its pathogenic mechanisms in addition to its clinical and epidemiological aspects; this review will attempt to build on previous studies in the periodontal literature in order to present an evidence-based comprehensive literature review on the effects of smoking on periodontal therapy.

MEDLINE searches were conducted to gather literature regarding the effects of smoking on various treatment outcomes using combinations of the key words smoking, tobacco, or cigarette smoking with periodontal therapy, scaling/root planing, antibiotics, gingival grafts, gingival recession, guided tissue regeneration, bone grafts, dental/oral implants and sinus grafting/lift. Searches were limited to the English language literature; no more restrictions were applied.

\section{Review}

\subsection{Effects of Smoking on Periodontal Therapy (Nonsurgical and Surgical Therapy)}

Since smokers have a higher prevalence and severity of periodontal disease, it is not surprising that they comprise a higher percentage of patients in periodontal practices compared to general dentistry practices [17]. A meta-analysis Labriola [1] evaluated the impact of smoking on nonsurgical therapy and found that probing depth reduction in sites where probing depth was initially $\geq 5 \mathrm{~mm}$ was significantly greater $(0.433 \mathrm{~mm})$ in nonsmokers than in smokers in eight studies [11] [18]-[24], Mongardini Clinical attachment level changes were reported for six of these studies, and the difference between smokers and nonsmokers at probing depths initially $\geq 5 \mathrm{~mm}$ was not statistically significant $(0.116 \mathrm{~mm})$; however, the results favored outcomes in nonsmokers [1]. These studies varied in the number of treatment sessions (one to eight), timing of post therapy evaluation (1 - 9 months), and definitions of smoking. In a separate study, not included in the previously described meta-analysis, treatment included 4 - 5 hours of scaling and root planing, oral hygiene instructions, and a session of scaling at 3 months [25]. Nonsmokers had $0.9 \mathrm{~mm}$ more probing depth reduction and $0.6 \mathrm{~mm}$ more clinical attachment gain at periodontitis sites (probing depth $\geq 5 \mathrm{~mm}$, clinical attachment level $\geq 3 \mathrm{~mm}$ ) compared to smokers at 6 months. In another more recent 6-month study which provided either same-day full-mouth scaling or quadrant scaling and root planing performed at 2-weekly intervals, Apatzdiou and co-workers found that, at probing depths initially $\geq 5 \mathrm{~mm}$, probing depth and clinical attachment improvements were $0.8 \mathrm{~mm}$ and $0.7 \mathrm{~mm}$ greater, respectively, in nonsmokers compared to smokers [26]. The majority of the previously described studies included subjects with chronic periodontitis. Results in patients with generalized aggressive periodontitis parallel these findings. In a group of patients with generalized aggressive periodontitis, Darby [27] reported $0.7 \mathrm{~mm}$ less improvement in probing depth and $0.4 \mathrm{~mm}$ less attachment gain in smokers compared to nonsmokers at the 6- to 8-week reevaluation following scaling and root planing [27]. These studies underscore the finding that the short term clinical response following nonsurgical treatment is compromised by smoking, with probing depth and attachment level improvements 50\% - 75\% those of nonsmokers.

The magnitude of difference in clinical outcomes following surgical therapy in smokers and nonsmokers parallels that seen for nonsurgical treatment. Following surgical treatment such as osseous surgery, modified Widman flap surgery, or flap debridement surgery, smokers had approximately $0.5 \mathrm{~mm}$ less improvement in probing depth and attachment levels, which was on average only $50 \%$ - $60 \%$ as much improvement as that in nonsmokers [28] [29]. In two studies there was a $1 \mathrm{~mm}$ difference between smokers and nonsmokers for both probing 
depth and clinical attachment level improvements at sites initially probing $\geq 7 \mathrm{~mm}$ [28] [30]. These differences remained over a 6-year maintenance period [28]. At furcation sites both horizontal and vertical attachment gain were mpaired by smoking [28] [31]. A trend has been noted for heavy smokers ( $\geq 20$ cigarettes per day) to respond less favorably to treatment than light smokers ( $<20$ cigarettes per day) [10]. Although the improvements in smokers are less than those for nonsmokers, it is important to recognize that smokers still benefit from both nonsurgical and surgical therapy.

\subsection{Periodontal Soft- and Hard-Tissue Grafting}

In a case series, Harris consecutively treated recession sites using a connective tissue with a partial thickness pedicle graft and found no difference between the percentage of root coverage among light smokers $(n=11,97 \%)$, heavy smokers ( $n=21,99 \%)$ or nonsmokers $(n=68,98 \%)$ [32]. In another report of 500 consecutively treated cases, the same clinician concluded that smoking $(n=68)$ did not contribute to post-surgical complications, although root coverage and gingival augmentation were not discussed in this study [33]. The majority of more recent studies indicate that smokers exhibit three-quarters of the amount of root coverage shown by nonsmokers. In studies involving 17 to 18 subjects, subepithelial connective-tissue grafts were less successful in smokers than nonsmokers [34] [35]. Erley and coworkers [35] and Martins et al. Martins [34] reported that root coverage was 82.3 and $58.4 \%$ for smokers, respectively, as compared to 98.3 and $74.73 \%$ for nonsmokers. Following a coronally positioned flap, root coverage was significantly less for 10 smokers compared to 10 nonsmokers (69.3\% vs. 91.3\%) [36]. When expanded polytetrafluoroethylene membranes were utilized in guided tissue regeneration procedures at recession sites, smokers had significantly less root coverage (57\%) than nonsmokers (78\%) [37]. In contrast, Amarante et al. found no difference in root coverage between smokers $(\mathrm{n}=8)$ and nonsmokers $(\mathrm{n}=$ 12) when recession defects were treated with a coronally repositioned flap alone or in combination with a bioabsorbable membrane [38]. In general, while smokers have more gingival recession than nonsmokers, and can benefit from root coverage procedures to treat recession, studies suggest that smoking negatively impacts the clinical outcomes of root coverage surgery.

Smoking has also been reported to negatively impact regenerative procedures in interproximal and furcation defects, including osseous grafts [39], membranes [34] [37] [40]-[43], or membranes in combination with osseous grafts [44] [45]. In these studies, smokers demonstrated approximately approximately half the amount of improvement in attachment levels compared to nonsmokers. This amounted to differences in clinical attachment levels between smokers and nonsmokers ranging from 0.35 [44] to $2.9 \mathrm{~mm}$ [40]. Osseous improvement as measured by bone sounding or re-entry was less in smokers $(0.1-0.5 \mathrm{~mm})$ compared to nonsmokers $(0.9-3.7$ $\mathrm{mm}$ ) [34] [37]. Bowers et al. found significantly more residual class II defects among smokers than nonsmokers (62.5\% vs. $14.3 \%)$ in furcations treated with a combination of demineralized freeze-dried bone allograft and a polytetrafluoroethylene membrane [45]. In contrast, Tsao et al. found that smoking had no effect on regenerative outcomes of mandibular class II furcation defects [46]. Smoking is one of the factors that impact the stability of treatment results. Five years after guided tissue regeneration or scaling and root planing, Cortellini and coworkers found that patients who smoked, had poor oral hygiene, were noncompliant with recalls and lost attachment of (2.2 - $2.4 \mathrm{~mm})$ [41]. These findings were confirmed in a longer term study of 175 patient followed for an average of 8 years after guided tissue regeneration therapy; smoking increased the probability of losing $\geq 2 \mathrm{~mm}$ attachment, whereas compliance with periodontal maintenance decreased the risk [47].

\subsection{Implant Therapy}

Many of the existing studies on implant outcomes in smokers are retrospective in nature or are case series and have included a variety of implant designs and surfaces, such as machined titanium, hydroxyapatite, and rough titanium, often within the same patient population. In the majority of these reports, smokers had at least twice the failure rate of implants compared to nonsmokers. Smoking has been acknowledged as a pre-disposing factor in implant failure, particularly in multiple failures in the same individual [48]. Even so, the survival rate ranged from $80 \%$ to $100 \%$ in smokers compared to $93 \%$ to $98 \%$ in nonsmokers [3] [15] [16] [49]-[52].

In 1991 a study was initiated that included 2887 implants, 62\% of which were hydroxyapatite-coated, placed in more than 800 patients at 32 clinical centers [50]. After 3 or more years, $8.9 \%$ of implants had failed in smokers compared to $6 \%$ in never or former smokers. The use of pre-operative antibiotics reduced failures in smokers by more than $10 \%$, compared to a $3 \%$ reduction in the nonsmoker/quit group. The percentage of maxil- 
lary implant failures among smokers $(10.9 \%)$ was higher than that reported for nonsmokers or past smokers (6.4\%) [50]. Other studies have found little difference between implant loss in the anterior mandible between smokers and nonsmokers [51] [53] [54], although longitudinal implant bone loss was greater for smokers than nonsmokers in this location [54]. Another study reported that survival of implants replacing molars (88\% mandibular molars) was not affected by smoking [55]. The majority of studies were focused on late implant placement, although a retrospective private practice study reported that smoking was not a factor in the failure of immediate implants [56]. Some investigators suggest that the advent of moderately rough titanium surface implants has resolved the differences between smokers and nonsmokers [48]. However, there are a limited number of studies, and those that exist provide mixed results. In studies assessing early healing, bone loss rates were similar in smokers and nonsmokers for rough-surfaced titanium implants [57] [58]. On the other hand, longer-term studies demonstrated that moderately rough-surfaced titanium implants experience more bone loss in smokers than in nonsmokers, especially in the maxillary arch [59] [60]. A 10-year retrospective private practice study reported that smoking was associated with implant loss in patients receiving ceramic blasted titanium screw designed implants. Failure rates were 15\% in current smokers, 9.6\% in former smokers, and 3.6\% in never smokers [61]. Implants are susceptible to the same bacterial and host influences as the natural dentition. Factors that interact with smoking to impact implant outcomes include an interleukin-1 genotype, implant location (maxillary vs. mandibular) and the presence of periodontal disease [60] [62]. The dose effect of smoking is another important consideration. A meta-analysis based on a multicenter clinical study reported that light smoking (12 cigarettes per day) did not impact the survival rate for machined or double acid-etched titanium surface implants. The implant surface did, however, affect outcomes. In both smokers and nonsmokers, the acidetched implants fared better than machined surface implants with overall 3-year survival rates of $98.7 \%$ vs. 93.5\%, respectively, in smokers and $98.4 \%$ vs. $92.8 \%$, respectively, in nonsmokers [63].

The implant failure rate in grafted maxillary sinuses in smokers was $12.7 \%$ compared to $4.8 \%$ in nonsmokers [64]; findings by Kan et al. parallel these results. This group reported that $17.1 \%$ of implants were lost in smokers, compared to $7 \%$ in nonsmokers, following maxillary sinus augmentation during a mean follow-up period of 41.6 months [65]. In a retrospective cohort study that included both maxillary sinus and ridge augmentation procedures, it was reported that smokers had a 4.4 times increased risk for implant failure, but overall survival rates at 1 and 5 years were still 95.2\% and 90.2\%, respectively [66] However, more postoperative complications following onlay bone grafting, such as graft exposure leading to graft removal, have been reported in smokers [67].

\subsection{Host Modulatory Therapy in Smokers}

The influence of tobacco on the host response and healing response may have several adverse effects on treatment outcomes in a variety of periodontal procedures. These adverse effects may occur through: the increased levels and/or activity of proteolytic enzymes directed against the structural elements of the periodontium; the elevation of destructive inflammatory cytokines; and/or suppression of the regenerative/reparative functions of the periodontium.

Because of the less favorable treatment response in smokers, clinicians may be more likely to utilize adjunctive antimicrobial therapy in these patients. When scaling and root planing were combined with adjunctive doxycycline gel or minocycline microspheres, the response in smokers was similar to that seen for nonsmokers receiving scaling and root planing alone [24] [68] [69]. In another study comparing adjunctive systemic antibiotic therapy to scaling and root planing alone, smokers receiving amoxicillin and metronidazole showed significantly more improvement in bleeding scores, probing depth and attachment levels than smokers receiving only scaling and root planing [70]. In addition to their antimicrobial activity, part of the benefit of locally delivered tetracycline derivatives may be derived from their anticollagenase activity. The fact that gingival fibroblasts had increased collagenase activity when exposed to nicotine in vitro [71] and that neutrophil elastase activity was increased in smokers' gingival crevice fluid compared to that of nonsmokers. Soder and colleagues [72] suggest that anti-collagenase host modulatory therapy in smokers may have potential. Perhaps the most widely used host modulators which may tip the balance toward regeneration/repair and away from destruction/inflammation are the tetracycline antibiotics, including tetracycline itself, doxycycline and minocycline. The tetracycline family of antibiotics may neutralize substances of inflammation that are particularly elevated in tobacco-associated periodontal diseases. In particular, the tetracyclines have been shown to depress the activity of several matrix me- 
talloproteinases (including collagenases), to inhibit the release of interleukin-1b from mononuclear cells, and to act as a scavenger for destructive oxygen species (such as superoxide), which are released during the oxidative burst [73]-[75]. These studies indirectly support the concept that the locally applied antibiotics of the tetracycline family may not only have an antimicrobial effect, but may also exert a local host modulating effect by protecting against some of the effects of smoke on the destructive/inflammatory arm of the host response.

\subsection{Maintenance Therapy}

The detrimental effects of smoking on treatment outcomes appear to be long lasting, and independent of the frequency of maintenance therapy. After four different modalities of therapy including scaling, scaling and root planing, modified Widman flap surgery, and osseous surgery, maintenance therapy was performed by a hygienist every 3 months for 7 years [10]. Smokers consistently had deeper pockets than nonsmokers and less gain in attachment when evaluated each year for the 7-year period. Heavy smokers ( $>20$ cigarettes/day) had more plaque than light smokers, former smokers, and nonsmokers. Even with more intensive maintenance therapy given every month for 6 months after flap surgery [30], smokers had deeper and more residual pockets than nonsmokers, even though no significant differences in plaque or bleeding on probing scores were found. These data suggest that the effects of smoking on the quality of subgingival plaque, the host response, and the healing characteristics of the periodontal tissues may have a long-term effect on pocket resolution in smokers that may not be managed by conventional periodontal therapy.

\section{Conclusion}

In view of the fact that the effects of smoking tip the balance towards periodontal destruction and impairment of regenerative responses, results in terms of improvements in clinical parameters show that smokers responses are around $50 \%$ that of nonsmokers. Adjunctive medications, such as systemic and locally delivered antibiotics and subantimicrobial dose of doxycycline in combination with regular maintenance care, are recommended in the management of the negative effects of smoking on the microbial and host factors involved in periodontitis. Additionally, close collaboration of dentists/periodontologists and physicians is recommended in the treatment of smoking patients since patients are likely to visit their periodontologist/dentist more often than their physician.

\section{References}

[1] Labriola, A., Needleman, I. and Moles, D.R. (2005) Systematic Review of the Effect of Smoking on Nonsurgical Periodontal Therapy. Periodontology, 37, 124-137. http://dx.doi.org/10.1111/j.1600-0757.2004.03793.x

[2] Haber, J., Wattles, J., Crowley, M., Mandell, R., Joshipura, K. and Kent, R.L. (1993) Evidence for Cigarette Smoking as a Major Risk Factor for Periodontitis. Journal of Periodontology, 64, 16-23.

http://dx.doi.org/10.1902/jop.1993.64.1.16

[3] Sgolastra, F., Petrucci, A., Severino, M., Gatto, R. and Monaco, A. (2014) Smoking and the Risk of Peri-Implantitis. A Systematic Review and Meta-Analysis. Clinical Oral Implants Research. http://dx.doi.org/10.1111/clr.12333

[4] Chambrone, L., Preshaw, P.M., Ferreira, J.D., Rodrigues, J.A., Cassoni, A. and Shibli, J.A. (2014) Effects of Tobacco Smoking on the Survival Rate of Dental Implants Placed in Areas of Maxillary Sinus Floor Augmentation: A Systematic Review. Clinical Oral Implants Research, 4, 408-416. http://dx.doi.org/10.1111/clr.12186

[5] Grossi, S.G., Genco, R.J., Machtei, E.E., Ho, A.W., Koch, G., Dunford, R., Zambon, J.J. and Hausmann, E. (1995) Assessment of Risk for Periodontal Disease. II. Risk Indicators for Alveolar Bone Loss. Journal of Periodontology, 66, 23-29. http://dx.doi.org/10.1902/jop.1995.66.1.23

[6] Hayman, L., Steffen, M.J., Stevens, J., Badger, E., Tempro, P., Fuller, B., McGuire, A., Al-Sabbagh, M., Thomas, M. V. and Ebersole, J.L. (2011) Smoking and Periodontal Disease: Discrimination of Antibody Responses to Pathogenic and Commensal Oral Bacteria. Clinical \& Experimental Immunology, 1, 118-126. http://dx.doi.org/10.1111/j.1365-2249.2010.04314.x

[7] Scott, D.A., Palmer, R.M. and Stapleton, J.A. (2001) Dose-Years as an Improved Index of Cumulative Tobacco Smoke Exposure. Medical Hypotheses, 56, 735-736. http://dx.doi.org/10.1054/mehy.2001.1238

[8] Molloy, J., Wolff, L.F., Lopez-Guzman, A. and Hodges, J.S. (2004) The Association of Periodontal Disease Parameters with Systemic Medical Conditions and Tobacco Use. Journal of Clinical Periodontology, 31, 625-632. http://dx.doi.org/10.1111/j.1600-051X.2004.00539.x

[9] Persson, R.E., Kiyak, A.H., Wyatt, C.C., Macentee, M. and Persson, G.R. (2005) Smoking, a Weak Predictor of Peri- 
odontitis in Older Adults. Journal of Clinical Periodontology, 32, 512-517. http://dx.doi.org/10.1111/j.1600-051X.2005.00701.x

[10] Kaldahl, W.B., Johnson, G.K., Patil, K.D. and Kalkwarf, K.L. (1996) Levels of Cigarette Consumption and Response to Periodontal Therapy. Journal of Periodontology, 67, 675-681. http://dx.doi.org/10.1902/jop.1996.67.7.675

[11] Grossi, S.G., Zambon, J., Machtei, E.E., Schifferle, R., Andreana, S., Genco, R.J., Cummins, D. and Harrap, G. (1997) Effects of Smoking and Smoking Cessation on Healing after Mechanical Periodontal Therapy. Journal of the American Dental Association, 128, 599-607. http://dx.doi.org/10.14219/jada.archive.1997.0259

[12] Stokholm, R., Isidor, F. and Nyengaard, J.R. (2013) Histologic and Histomorphometric Evaluation of Peri-Implant Bone of Immediate or Delayed Occlusal-Loaded Non-Splinted Implants in the Posterior Mandible-An Experimental Study in Monkeys. Clinical Oral Implants Research. http://dx.doi.org/10.1111/clr.12274

[13] Pellicer-Chover, H., Vi-a-Almunia, J., Romero-Millán, J., Pearrocha-Oltra, D., García-Mira, B. and Pearrocha-Diago, M. (2013) Influence of Occlusal Loading on Peri-Implant Clinical Parameters. A Pilot Study. Clinical Oral Implants Research.

[14] Quirynen, M., Naert, I. and van, S.D. (1992) Fixture Design and Overload Influence Marginal Bone Loss and Fixture Success in the Branemark System. Clinical Oral Implants Research, 3, 104-111. http://dx.doi.org/10.1034/j.1600-0501.1992.030302.x

[15] Levin, L. and Kessler-Baruch, O. (2013) Cigarette Smoking and the Alveolar Bone around Teeth and Dental Implants. Review. New York State Dental Journal, 5, 53-59.

[16] Alsaadi, G., Quirynen, M., Michiles, K., Teughels, W., Komarek, A. and van, S. D. (2008) Impact of Local and Systemic Factors on the Incidence of Failures up to Abutment Connection with Modified Surface Oral Implants. Journal of Clinical Periodontology, 35, 51-57.

[17] Haber, J. and Kent, R.L. (1992) Cigarette Smoking in a Periodontal Practice. Journal of Periodontology, 63, 100-106. http://dx.doi.org/10.1902/jop.1992.63.2.100

[18] Mongardini, C., van, S.D., Dekeyser, C. and Quirynen, M. (1999) One Stage Full- versus Partial-Mouth Disinfection in the Treatment of Chronic Adult or Generalized Early-Onset Periodontitis. I. Long-Term Clinical Observations. Journal of Periodontology, 70, 632-645. http://dx.doi.org/10.1902/jop.1999.70.6.632

[19] Palmer, R.M., Scott, D.A., Meekin, T.N., Poston, R.N., Odell, E.W. and Wilson, R.F. (1999) Potential Mechanisms of Susceptibility to Periodontitis in Tobacco Smokers. Journal of Periodontal Research, 34, 363-369. http://dx.doi.org/10.1111/j.1600-0765.1999.tb02267.x

[20] Bizzarro, S., Loos, B.G., Laine, M.L., Crielaard, W. and Zaura, E. (2013) Subgingival Microbiome in Smokers and Non-Smokers in Periodontitis: An Exploratory Study Using Traditional Targeted Techniques and a Next-Generation Sequencing. Journal of Clinical Periodontology, 5, 483-492. http://dx.doi.org/10.1111/jcpe.12087

[21] Matthews, C.R., Joshi, V., de Jager, M., Aspiras, M. and Kumar, P.S. (2013) Host-Bacterial Interactions during Induction and Resolution of Experimental Gingivitis in Current Smokers. Journal of Periodontology, 1, 32-40. http://dx.doi.org/10.1902/jop.2012.110662

[22] Renvert, S., Dahlen, G. and Wikstrom, M. (1998) The Clinical and Microbiological Effects of Non-Surgical Periodontal Therapy in Smokers and Non-Smokers. Journal of Clinical Periodontology, 25, 153-157. http://dx.doi.org/10.1111/j.1600-051X.1998.tb02421.x

[23] Ryder, M.I., Pons, B., Adams, D., Beiswanger, B., Blanco, V., Bogle, G., Donly, K., Hallmon, W., Hancock, E.B., Hanes, P., Hawley, C., Johnson, L., Wang, H.L., Wolinsky, L., Yukna, R., Polson, A., Carron, G. and Garrett, S. (1999) Effects of Smoking on Local Delivery of Controlled-Release Doxycycline as Compared to Scaling and Root Planing. Journal of Clinical Periodontology, 26, 683-691. http://dx.doi.org/10.1034/j.1600-051X.1999.261008.x

[24] Williams, R.C., Paquette, D.W., Offenbacher, S., Adams, D.F., Armitage, G.C., Bray, K., Caton, J., Cochran, D.L., Drisko, C.H., Fiorellini, J.P., Giannobile, W.V., Grossi, S., Guerrero, D.M., Johnson, G.K., Lamster, I.B., Magnusson, I., Oringer, R.J., Persson, G.R., Van Dyke, T.E., Wolff, L.F., Santucci, E.A., Rodda, B.E. and Lessem, J. (2001) Treatment of Periodontitis by Local Administration of Minocycline Microspheres: A Controlled Trial. Journal of Periodontology, 72, 1535-1544. http://dx.doi.org/10.1902/jop.2001.72.11.1535

[25] Jin, L., Wong, K.Y., Leung, W.K. and Corbet, E.F. (2000) Comparison of Treatment Response Patterns Following Scaling and Root Planing in Smokers and Non-Smokers with Untreated Adult Periodontitis. Journal of Clinical Dentistry, 11, 35-41.

[26] Apatzidou, D.A., Riggio, M.P. and Kinane, D.F. (2005) Impact of Smoking on the Clinical, Microbiological and Immunological Parameters of Adult Patients with Periodontitis. Journal of Clinical Periodontology, 32, 973-983. http://dx.doi.org/10.1111/j.1600-051X.2005.00788.x

[27] Darby, I.B., Hodge, P.J., Riggio, M.P. and Kinane, D.F. (2005) Clinical and Microbiological Effect of Scaling and Root Planing in Smoker and Non-Smoker Chronic and Aggressive Periodontitis Patients. Journal of Clinical Peri- 
odontology, 32, 200-206. http://dx.doi.org/10.1111/j.1600-051X.2005.00644.x

[28] Guarnelli, M.E., Farina, R., Cucchi, A. and Trombelli, L. (2010) Clinical and Microbiological Effects of Mechanical Instrumentation and Local Antimicrobials during Periodontal Supportive Therapy in Aggressive Periodontitis Patients: Smoker versus Non-Smoker Patients. Journal of Clinical Periodontology, 11, 998-1004. http://dx.doi.org/10.1111/j.1600-051X.2010.01623.x

[29] Preber, H. and Bergstrom, J. (1990) Effect of Cigarette Smoking on Periodontal Healing Following Surgical Therapy. Journal of Clinical Periodontology, 17, 324-328. http://dx.doi.org/10.1111/j.1600-051X.1990.tb01098.x

[30] Scabbia, A., Cho, K.S., Sigurdsson, T.J., Kim, C.K. and Trombelli, L. (2001) Cigarette Smoking Negatively Affects Healing Response Following Flap Debridement Surgery. Journal of Periodontology, 72, 43-49. http://dx.doi.org/10.1902/jop.2001.72.1.43

[31] Trombelli, L., Cho, K.S., Kim, C.K., Scapoli, C. and Scabbia, A. (2003) Impaired Healing Response of Periodontal Furcation Defects Following Flap Debridement Surgery in Smokers. A Controlled Clinical Trial. Journal of Clinical Periodontology, 30, 81-87. http://dx.doi.org/10.1034/j.1600-051X.2003.10182.X

[32] Zucchelli, G., Mounssif, I., Mazzotti, C., Stefanini, M., Marzadori, M., Petracci, E. and Montebugnoli, L. (2014) Coronally Advanced Flap with and without Connective Tissue Graft for the Treatment of Multiple Gingival Recessions: A Comparative Short- and Long-Term Controlled Randomized Clinical Trial. Journal of Clinical Periodontology, 41, 396-403.

[33] Harris, R.J., Miller, L.H., Harris, C.R. and Miller, R.J. (2005) A Comparison of Three Techniques to Obtain Root Coverage on Mandibular Incisors. Journal of Periodontology, 76, 1758-1767. http://dx.doi.org/10.1902/jop.2005.76.10.1758

[34] Nanavati, B., Bhavsar, N. and Jaydeepchandra, M. (2013) Coronally Positioned Flap for Root Coverage: Comparison between Smokers and Nonsmokers. Review. Journal of International Oral Health, 5, 21-27.

[35] Erley, K.J., Swiec, G.D., Herold, R., Bisch, F.C. and Peacock, M.E. (2006) Gingival Recession Treatment with Connective Tissue Grafts in Smokers and Non-Smokers. Journal of Periodontology, 77, 1148-1155. http://dx.doi.org/10.1902/jop.2006.050252

[36] Silva, C.O., Sallum, A.W., de Lima, A.F. and Tatakis, D.N. (2006) Coronally Positioned Flap for Root Coverage: Poorer Outcomes in Smokers. Journal of Periodontology, 77, 81-87. http://dx.doi.org/10.1902/jop.2006.77.1.81

[37] Trombelli, L. and Scabbia, A. (1997) Healing Response of Gingival Recession Defects Following Guided Tissue Regeneration Procedures in Smokers and Non-Smokers. Journal of Clinical Periodontology, 24, 529-533. http://dx.doi.org/10.1111/j.1600-051X.1997.tb00224.x

[38] Amarante, E.S., Leknes, K.N., Skavland, J. and Lie, T. (2000) Coronally Positioned Flap Procedures with or without a Bioabsorbable Membrane in the Treatment of Human Gingival Recession. Journal of Periodontology, 71, 989-998. http://dx.doi.org/10.1902/jop.2000.71.6.989

[39] Rosen, P.S., Bowers, G.M. and Marks, M.H. (1996) Modifications of the Subpedicle Connective Tissue Graft Technique: A Predictable Procedure for Covering Exposed Roots. Compendium of Continuing Education in Dentistry, 17, 440-442,444.

[40] Needleman, I.G., Worthington, H.V., Giedrys-Leeper, E. and Tucker, R.J. (2006) Guided Tissue Regeneration for Periodontal Infra-Bony Defects. Cochrane Database of Systematic Reviews, 2, Article ID: CD001724.

[41] Cortellini, P., Pini, P.G. and Tonetti, M.S. (1996) Periodontal Regeneration of Human Intrabony Defects with Bioresorbable Membranes. A Controlled Clinical Trial. Journal of Periodontology, 67, 217-223. http://dx.doi.org/10.1902/jop.1996.67.3.217

[42] Loos, B.G., Louwerse, P.H., Van Winkelhoff, A.J., Burger, W., Gilijamse, M., Hart, A.A. and Van Der Velden, U. (2002) Use of Barrier Membranes and Systemic Antibiotics in the Treatment of Intraosseous Defects. Journal of Clinical Periodontology, 29, 910-921. http://dx.doi.org/10.1034/j.1600-051X.2002.291006.X

[43] Stavropoulos, A., Mardas, N., Herrero, F. and Karring, T. (2004) Smoking Affects the Outcome of Guided Tissue Regeneration with Bioresorbable Membranes: A Retrospective Analysis of Intrabony Defects. Journal of Clinical Periodontology, 31, 945-950. http://dx.doi.org/10.1111/j.1600-051X.2004.00589.x

[44] Luepke, P.G., Mellonig, J.T. and Brunsvold, M.A. (1997) A Clinical Evaluation of a Bioresorbable Barrier with and without Decalcified Freeze-Dried Bone Allograft in the Treatment of Molar Furcations. Journal of Clinical Periodontology, 24, 440-446. http://dx.doi.org/10.1111/j.1600-051X.1997.tb00209.x

[45] Bowers, G.M., Schallhorn, R.G., McClain, P.K., Morrison, G.M., Morgan, R. and Reynolds, M.A. (2003) Factors Influencing the Outcome of Regenerative Therapy in Mandibular Class II Furcations: Part I. Journal of Periodontology, 74, 1255-1268. http://dx.doi.org/10.1902/jop.2003.74.9.1255

[46] Tsao, Y.P., Neiva, R., Al-Shammari, K., Oh, T.J. and Wang, H.L. (2006) Factors Influencing Treatment Outcomes in Mandibular Class II Furcation Defects. Journal of Periodontology, 77, 641-646. http://dx.doi.org/10.1902/jop.2006.050133 
[47] Cortellini, P. and Tonetti, M.S. (2004) Long-Term Tooth Survival Following Regenerative Treatment of Intrabony Defects. Journal of Periodontology, 75, 672-678. http://dx.doi.org/10.1902/jop.2004.75.5.672

[48] Bain, C.A. (2003) Implant Installation in the Smoking Patient. Periodontology, 33, 185-193. http://dx.doi.org/10.1046/j.0906-6713.2003.03315.x

[49] Gorman, L.M., Lambert, P.M., Morris, H.F., Ochi, S. and Winkler, S. (1994) The Effect of Smoking on Implant Survival at Second-Stage Surgery: DICRG Interim Report No. 5. Dental Implant Clinical Research Group. Implant Dentistry, 3, 165-168. http://dx.doi.org/10.1097/00008505-199409000-00004

[50] Lambert, P.M., Morris, H.F. and Ochi, S. (2000) The Influence of Smoking on 3-Year Clinical Success of Osseointegrated Dental Implants. Annals of Periodontology, 5, 79-89. http://dx.doi.org/10.1902/annals.2000.5.1.79

[51] Wallace, R.H. (2000) The Relationship between Cigarette Smoking and Dental Implant Failure. European Journal of Prosthodontics and Restorative Dentistry, 8, 103-106.

[52] Chuang, S.K., Wei, L.J., Douglass, C.W. and Dodson, T.B. (2002) Risk Factors for Dental Implant Failure: A Strategy for the Analysis of Clustered Failure-Time Observations. Journal of Dental Research, 81, 572-577. http://dx.doi.org/10.1177/154405910208100814

[53] Lindquist, L.W., Carlsson, G.E. and Jemt, T. (1996) A Prospective 15-Year Follow-Up Study of Mandibular Fixed Prostheses Supported by Osseointegrated Implants. Clinical Results and Marginal Bone Loss. Clinical Oral Implants Research, 7, 329-336. http://dx.doi.org/10.1034/j.1600-0501.1996.070405.x

[54] Lindquist, L.W., Carlsson, G.E. and Jemt, T. (1997) Association between Marginal Bone Loss around Osseointegrated Mandibular Implants and Smoking Habits: A 10-Year Follow-Up Study. Journal of Dental Research, 76, 1667-1674. http://dx.doi.org/10.1177/00220345970760100801

[55] Levin, L., Sadet, P. and Grossmann, Y. (2006) A Retrospective Evaluation of 1,387 Single-Tooth Implants: A 6-Year Follow-Up. Journal of Periodontology, 77, 2080-2083. http://dx.doi.org/10.1902/jop.2006.060220

[56] Wagenberg, B. and Froum, S.J. (2006) A Retrospective Study of 1925 Consecutively Placed Immediate Implants from 1988 to 2004. International Journal of Oral \& Maxillofacial Implants, 21, 71-80.

[57] Kumar, A., Jaffin, R.A. and Berman, C. (2002) The Effect of Smoking on Achieving Osseointegration of Surface-Modified Implants: A Clinical Report. International Journal of Oral \& Maxillofacial Implants, 17, 816-819.

[58] Shimpuku, H., Nosaka, Y., Kawamura, T., Tachi, Y., Shinohara, M. and Ohura, K. (2003) Genetic Polymorphisms of the Interleukin-1 Gene and Early Marginal Bone Loss around Endosseous Dental Implants. Clinical Oral Implants Research, 14, 423-429. http://dx.doi.org/10.1034/j.1600-0501.2003.110823.x

[59] Penarrocha, M., Palomar, M., Sanchis, J.M., Guarinos, J. and Balaguer, J. (2004) Radiologic Study of Marginal Bone Loss around 108 Dental Implants and Its Relationship to Smoking, Implant Location, and Morphology. International Journal of Oral \& Maxillofacial Implants, 19, 861-867.

[60] Wennstrom, J., Zurdo, J., Karlsson, S., Ekestubbe, A., Grondahl, K. and Lindhe, J. (2004) Bone Level Change at ImplantSupported Fixed Partial Dentures with and without Cantilever Extension after 5 Years in Function. Journal of Clinical Periodontology, 31, 1077-1083. http://dx.doi.org/10.1111/j.1600-051X.2004.00603.x

[61] Mundt, T., Mack, F., Schwahn, C. and Biffar, R. (2006) Private Practice Results of Screw-Type Tapered Implants: Survival and Evaluation of Risk Factors. International Journal of Oral \& Maxillofacial Implants, 21, 607-614.

[62] Roos-Jansaker, A.M., Lindahl, C., Renvert, H. and Renvert, S. (2006) Nine- to Fourteen-Year Follow-Up of Implant Treatment. Part I: Implant Loss and Associations to Various Factors. Journal of Clinical Periodontology, 33, $283-289$. http://dx.doi.org/10.1111/j.1600-051X.2006.00907.x

[63] Bain, C.A., Weng, D., Meltzer, A., Kohles, S.S. and Stach, R.M. (2002) A Meta-Analysis Evaluating the Risk for Implant Failure in Patients Who Smoke. Compendium of Continuing Education in Dentistry, 23, 695-699,702,704.

[64] Geurs, N.C., Wang, I.C., Shulman, L.B. and Jeffcoat, M.K. (2001) Retrospective Radiographic Analysis of Sinus Graft and Implant Placement Procedures from the Academy of Osseointegration Consensus Conference on Sinus Grafts. International Journal of Periodontics \& Restorative Dentistry, 21, 517-523.

[65] Galindo-Moreno, P., Fernández-Jiménez, A., O’Valle, F., Silvestre, F.J., Sánchez-Fernández, E., Monje, A. and Catena, A. (2013) Marginal Bone Loss in Implants Placed in Grafted Maxillary Sinus. Clinical Implant Dentistry and Related Research. http://dx.doi.org/10.1111/cid.12092

[66] Woo, V.V., Chuang, S.K., Daher, S., Muftu, A. and Dodson, T.B. (2004) Dentoalveolar Reconstructive Procedures as a Risk Factor for Implant Failure. Journal of Oral and Maxillofacial Surgery, 62, 773-780. http://dx.doi.org/10.1016/j.joms.2003.12.017

[67] Levin, L., Herzberg, R., Dolev, E. and Schwartz-Arad, D. (2004) Smoking and Complications of Onlay Bone Grafts and Sinus Lift Operations. International Journal of Oral \& Maxillofacial Implants, 19, 369-373.

[68] Paquette, D., Oringer, R., Lessem, J., Offenbacher, S., Genco, R., Persson, G.R., Santucci, E.A. and Williams, R.C. (2003) 
Locally Delivered Minocycline Microspheres for the Treatment of Periodontitis in Smokers. Journal of Clinical Periodontology, 30, 787-794. http://dx.doi.org/10.1034/j.1600-051X.2003.00375.x

[69] Tomasi, C. and Wennstrom, J.L. (2004) Locally Delivered Doxycycline Improves the Healing Following Non-Surgical Periodontal Therapy in Smokers. Journal of Clinical Periodontology, 31, 589-595. http://dx.doi.org/10.1111/j.1600-051X.2004.00524.x

[70] Winkel, E.G., Van Winkelhoff, A.J., Timmerman, M.F., Van der Velden, U. and Van der Weijden, G.A. (2001) Amoxicillin Plus Metronidazole in the Treatment of Adult Periodontitis Patients. A Double-Blind Placebo-Controlled Study. Journal of Clinical Periodontology, 28, 296-305. http://dx.doi.org/10.1034/j.1600-051x.2001.028004296.x

[71] Tipton, D.A. and Dabbous, M.K. (1995) Effects of Nicotine on Proliferation and Extracellular Matrix Production of Human Gingival Fibroblasts in Vitro. Journal of Periodontology, 66, 1056-1064. http://dx.doi.org/10.1902/jop.1995.66.12.1056

[72] Soder, B., Nedlich, U. and Jin, L.J. (1999) Longitudinal Effect of Non-Surgical Treatment and Systemic Metronidazole for 1 Week in Smokers and Non-Smokers with Refractory Periodontitis: A 5-Year Study. Journal of Periodontology, 70, 761-771. http://dx.doi.org/10.1902/jop.1999.70.7.761

[73] Akamatsu, H., Kurokawa, I., Nishijima, S. and Asada, Y. (1992) Inhibition of Neutrophil Chemotactic Factor Production in Comedonal Bacteria by Subminimal Inhibitory Concentrations of Erythromycin. Dermatology, 185, 41-43. http://dx.doi.org/10.1159/000247401

[74] Matesanz-Pérez, P., García-Gargallo, M., Figuero, E., Bascones-Martínez, A., Sanz, M. and Herrera D. (2013) A Systematic Review on the Effects of Local Antimicrobials as Adjuncts to Subgingival Debridement, Compared with Subgingival Debridement Alone, in the Treatment of Chronic Periodontitis. Journal of Clinical Periodontology, 40, 227241. http://dx.doi.org/10.1111/jcpe.12026

[75] Golub, L.M., Lee, H.M., Ryan, M.E., Giannobile, W.V., Payne, J. and Sorsa, T. (1998) Tetracyclines Inhibit Connective Tissue Breakdown by Multiple Non-Antimicrobial Mechanisms. Advances in Dental Research, 12, 12-26. http://dx.doi.org/10.1177/08959374980120010501 